\title{
Identification and functional characterization of the pheromone biosynthesis activating neuropeptide receptor isoforms from Mamestra brassicae
}

\author{
József Fodor $^{\mathrm{a}, 1}$, J. Joe Hull ${ }^{\mathrm{b}, 1}$, Gabriella Köblös ${ }^{\mathrm{a}, *}$, Emmanuelle Jacquin-Joly ${ }^{\mathrm{c}}$, Tamás Szlanka ${ }^{\mathrm{d}}$, Adrien Fónagy \\ a Plant Protection Institute, Centre for Agricultural Research, Hungarian Academy of Sciences, H-1022 Budapest, Hungary \\ b Agricultural Research Service, United States Department of Agriculture, Arid Land Agricultural Research Center, Maricopa, AZ, USA \\ c INRA iEES-Paris, Institute of Ecology and Environmental Sciences, Route de Saint-Cyr, Cedex 78026 Versailles, France \\ d Institute of Biochemistry, Biological Research Centre, Hungarian Academy of Sciences, H-6726 Szeged, Hungary
}

\section{A R T I C L E I N F O}

Article history

Received 3 March 2017

Received in revised form 26 May 2017

Accepted 31 May 2017

Available online xxx

\section{Keywords:}

Mamestra brassicae

Pheromone biosynthesis activating neuropeptide receptor (PBANR)

PBAN

Confocal microscopy

$\mathrm{Ca}^{2+}$ imaging

Receptor internalization

\section{A B S T R A C T}

In most moth species, including Mamestra brassicae, pheromone biosynthesis activating neuropeptide (PBAN) regulates pheromone production. Generally, PBAN acts directly on the pheromone gland (PG) cells via its specific G-protein-coupled receptor (i.e. PBANR) with $\mathrm{Ca}^{2+}$ as a second messenger. In this study, we identified cDNAs encoding three variants (A, B and C) of the M. brassicae PBANR (Mambr-PBANR). The full-length coding sequences were transiently expressed in cultured Trichoplusia ni cells and Sf9 cells for functional characterization. All three isoforms dose-dependently mobilized extracellular $\mathrm{Ca}^{2+}$ in response to PBAN analogs with Mambr-PBANR-C exhibiting the greatest sensitivity. Fluorescent confocal microscopy imaging studies demonstrated binding of a rhodamine red-labeled ligand (RR10CPBAN) to all three Mambr-PBANR isoforms. RR10CPBAN binding did not trigger ligand-induced internalization in cells expressing PBANR-A, but did in cells expressing the PBANR-B and -C isoforms. Furthermore, activation of the PBANR-B and -C isoforms with the 18 amino acid Mambr-pheromonotropin resulted in co-localization with a Drosophila melanogaster arrestin homolog (Kurtz), whereas stimulation with an unrelated peptide had no effect. PCR-based profiling of the three transcripts revealed a basal level of expression throughout development with a dramatic increase in PG transcripts from the day of adult emergence with PBANR-C being the most abundant.

(C) 2017 Published by Elsevier Ltd.

\section{Introduction}

The vast majority of sexually receptive female moths produce species-specific sex pheromones to attract conspecific males (Karlson and Butenandt, 1959). These compounds are usually de novo synthesized via a modified fatty acid (FA) biosynthetic pathway (Rafaeli, 2002; Tillman et al., 1999). Biosynthesis and release typically takes place within the specialized epidermal tissue that comprises the pheromone gland (PG), which is located at the intersegmental membrane between the 8 and 9th abdominal segment (Blomquist and Vogt, 2003; Percy and Weatherston, 1974).

In recent years, understanding of the biosynthetic pathways underlying lepidopteran pheromone production and its regulation has been greatly expanded (Blomquist et al., 2011; Jurenka, 2004; Jurenka and Rafaeli, 2011; Matsumoto et al., 2007; Rafaeli, 2011). In mature virgin females, both pheromone production and release are synchronized by the circadian-regulated action of pheromone biosynthesis

\footnotetext{
* Corresponding author.

Email address: koblos.gabriella@agrar.mta.hu (G. Köblös)

${ }^{1}$ Equal contribution.
}

activating neuropeptide (PBAN), which originates from the subesophageal ganglion (SEG) (Raina et al., 1989). PBAN is a member of an ancient conserved signaling family of peptides characterized by a C-terminal amidated pentapeptide FXPRL-amide $(X=S, T, G$ or V) that is essential for the pheromonotropic activity of PBAN (Kuniyoshi et al., 1991; Raina and Kempe, 1990). Post-translational processing of the PBAN prepropeptide yields PBAN as well as four additional FXPRL-amide peptides i.e. diapause hormone and $\alpha-, \beta$ - and $\gamma$-SEG neuropeptides (SGNPs) that exhibit varying degrees of pheromonotropic activity (Ma et al., 1994, 1996; Sato et al., 1993).

Pheromone production is initiated by specific binding of PBAN to its cognate receptor (PBANR) expressed at the cell surface of PG cells. Although demonstrated histochemically in Heliothis peltigera PGs (Altstein et al., 2003), the molecular identity of the PBANR proved elusive until sequence similarities between predicted Drosophila G protein-coupled receptors (GPCRs) and mammalian receptors suggested that FXPRL-amide receptors, such as PBANR, belong to the mammalian neuromedin $U$ receptor family (Hewes and Taghert, 2001). Subsequent confirmation of this hypothesis (Park et al., 2002) facilitated homology-based identification of the PBANR in Helicoverpa zea (Choi et al., 2003) and Bombyx mori (Hull et al., 2004). Since then PBANRs have been identified in diverse moth 
species (Cheng et al., 2010; Ding and Löfstedt, 2015; Kim et al., 2008; Lee et al., 2012; Nusawardani et al., 2013; Rafaeli et al., 2007; Zheng et al., 2007) with multiple PBANR isoforms (PBANR-As, -A, -B, and -C) shown to be concomitantly expressed in PGs (Kim et al., 2008; Lee et al., 2012). The isoforms are differentiated by the length and composition of their C-termini, which is necessary for the ligand-induced internalization (Hull et al., 2005), a phase of GPCR feedback regulation and desensitization (Moore et al., 2007; Marchese et al., 2008). The "short" PBANRs lack a C-terminal extension and exhibit different internalization kinetics as compared to the "long" isoforms (Lee et al., 2012). The differing responses of the isoforms, which arise from alternative splicing of the C-terminus (Kim et al., 2008; Lee et al., 2012), have been suggested to reflect the pleiotropic nature of the PK/PBAN signaling system in insects (Nusawardani et al., 2013). Despite these structural differences and variation in the downstream intracellular signal transduction cascade (Hull et al., 2007a; Matsumoto et al., 1995; Rafaeli et al., 1990; Rafaeli and Soroker, 1989), PBANRs are characterized by PBAN-mediated mobilization of extracellular $\mathrm{Ca}^{2+}$, which is a prerequisite for turning the PBAN signal into the biological response of sex pheromone production (see reviews: Matsumoto et al., 2010; Rafaeli, 2009).

Although not as extensively studied as the two main model systems (i.e. B. mori and H. zea), Mamestra brassicae has also been the focus of numerous pheromonotropic-based studies. Immunocytochemical studies revealed the presence of PBAN-like peptides in the hemolymph at 100-500 pM during the scotophase (Iglesias et al., 1999) and a cDNA clone of the PBAN coding sequence with significant homology to $H$. zea PBAN (Helze-PBAN) has been reported (Jacquin-Joly et al., 1998). In addition, a pheromonotropic 18-aa SGNP, referred to as Mambr-PT (Fónagy et al., 1998, 2008), with close sequence similarity to $\beta$-SGNPs identified in $B$. mori, H. assulta, H. zea, and Pseudalatia separata (Altstein et al., 2013; Jurenka, 2015; Rafaeli, 2009) has been identified. More recently, an extensive study examining the time course of $M$. brassicae pheromone production in relation to a desaturase further revealed the pheromonotropic effects of Mambr-PT (Köblös et al., 2015). Despite these findings, the PBANR of $M$. brassicae remains unknown. The objective of this study was to clone and characterize PBANRs in the pest M. brassicae and to determine if these receptors are functionally similar to those described in other noctuid moths (Jurenka and Rafaeli, 2011). The generation of new insights into PBANR - PBAN interactions may elicit species specific control of pheromone production in pest management and provide a potentially deeper understanding to facilitate the development of new antagonists (Nachman et al., 2009).

\section{Materials and methods}

\subsection{Insects}

A laboratory culture of $M$. brassicae was established using adults collected from fields in different regions of Hungary and maintained under a reverse photoperiod of $16: 8 \mathrm{~h} \mathrm{light/dark}$ cycle at $25{ }^{\circ} \mathrm{C}, 50 \%$ relative humidity. Larvae were reared on a semi-synthetic diet (Nagy, 1970). Pupae were sexed and separated and after moth emergence, adults were kept separately in glass jars $(12 \times 10 \mathrm{~cm})$ covered with fine mesh and fed a $10 \%$ honey solution supplied on cotton pads.

\subsection{Cloning and sequence analysis}

Total RNA was isolated from PGs of 2-3-day-old calling females using Extractme Total RNA kit (Blirt SA, DNA-Gdańsk, Gdańsk,
Poland) and reverse transcribed using SuperScript III reverse transcriptase and random hexamer primers (Invitrogen, Carlsbad, CA) according to the manufacturer's instructions. A 1208-bp fragment of M. brassicae PBANR (Mambr-PBANR) was amplified with degenerate primers (sense 5'-CGCCGCAACTYYGTCGTTC-3' and antisense 5'-TRAAGGCGTTTCTGAACTTRTT-3') corresponding to conserved regions of published PBANR sequences. PCR amplification was carried out using Phusion DNA polymerase in HF buffer (Thermo Fisher Scientific, Waltham, MA) under the following conditions: $98^{\circ} \mathrm{C}$ for $1.5 \mathrm{~min}, 35$ cycles at $98^{\circ} \mathrm{C}$ for $15 \mathrm{~s}, 59^{\circ} \mathrm{C}$ for $30 \mathrm{~s}$ and $72{ }^{\circ} \mathrm{C}$ for $40 \mathrm{~s}$, followed by a final extension of $72^{\circ} \mathrm{C}$ for $5 \mathrm{~min}$. The amplified PCR products were ligated into the $\mathrm{pJET} 1.2 / \mathrm{blunt}$ cloning vector using a CloneJET PCR cloning kit (Fermentas, Glen Burnie, MD) according to the manufacturer's protocols and sequence verified (Macrogen Europe, Amsterdam, The Netherlands).

Sequence information from the cloned cDNA fragments was used to design gene-specific primers using Primer-BLAST (http://www. ncbi.nlm.nih.gov/tools/primer-blast). Full-length cDNA sequences were determined by 5'- and 3'-rapid amplification of cDNA ends (RACE) using a SMARTer RACE cDNA amplification kit (Clontech, Palo Alto, CA) according to the recommendations of the manufacturer. The two specific primers designed from the partial cDNA fragment were 5'-GAGTGGGCAGATGCAGTACAG-3' for 3' RACE, and 5'-CTTGAACAGTAGACGCGGAACAT-3' for 5' RACE. The sequences have been deposited in GenBank under accession Nos. KX831609-KX831611.

Sequence alignments of the putative protein sequences were performed with ClustalX 2.1 (Thompson et al., 1997). Transmembrane regions of the PBANR proteins were predicted using TMHMM 2.0 (http://www.cbs.dtu.dk/services/TMHMM) (Krogh et al., 2001). Phylogenetic analysis of the putative Mambr-PBANR sequences was performed in conjunction with other lepidopteran PBANR sequences obtained from BLAST searches. The phylogenetic evolutionary history was inferred using the Maximum-Likelihood method according to the Le-Gascuel model (Le and Gascuel, 2008) implemented in MEGA 6 (Tamura et al., 2013) with bootstrap support based on 1000 iterations.

\subsection{Construction of insect expression plasmids}

To examine the cellular localization of the Mambr-PBANR isoforms and ligand binding, chimeras of each isoform were constructed with the fluorescent protein mVenus (Nagai et al., 2002) fused in-frame to the receptor C-terminus. Expression vectors were constructed using a pIB/V5-His-TOPO TA insect expression vector (Thermo Fisher Scientific, Waltham, MA) containing the mVenus coding sequence engineered with a 5 '-StuI restriction site (i.e. pIB/ StuI-mVenus). The variants were amplified using a gene specific ORF sense primer (5'-AAGATGACATTGCCAGTGCC-3') and variant specific antisense primers (PBANR-A: 5'-CCTCAATACAAGTAGATCAATCATA-3'; PBANR-B: 5'-CCTGGTGAGTCCGCCGAT-3'; PBANR-C: 5'-CCTCGTGGTACATGTAGGTGG-3') that replaced the stop codon with an in-frame StuI restriction site. The amplified PCR products were then cloned into the StuI restriction site of the $\mathrm{mVenus}$ expression vector. The resulting constructs were sequence validated prior to use.

\subsection{Confocal microscopy of transiently expressed Mambr-PBANR chimeras in cultured insect cells}

Adherent Trichoplusia ni (Tni) cells (Allele Biotechnology, San Diego, CA), passaged and maintained in serum-free insect culture media (Allele Biotechnology), were seeded onto $35 \mathrm{~mm} \# 1.5$ glass 
bottom dishes (Matsunami Glass USA Inc., Bellingham, WA) and transfected using 2- $\mu \mathrm{g}$ plasmid with $4 \mu \mathrm{L}$ Insect Gene Juice transfection reagent (Novagen, EMD Biosciences, San Diego, CA). After $5 \mathrm{~h}$, the transfection media was discarded and the cells maintained in serum-free media for $48 \mathrm{~h}$ at $28^{\circ} \mathrm{C}$. Tni cells transiently expressing the chimeric Mambr-PBANR isoforms were incubated for $1 \mathrm{~h}$ at $4{ }^{\circ} \mathrm{C}$ with $50 \mathrm{nM}$ of a fluorescently labeled synthetic B. mori PBAN ana$\log$ (RR-C10PBANR) prepared previously (Lee et al., 2012). Cells were then rinsed twice and imaged in $2 \mathrm{~mL}$ cold IPL-41 insect media (Thermo Fisher Scientific) on a Fluoview FV10i-LIV fluorescent confocal laser-scanning microscope (Olympus, Center Valley, PA) using a $60 \times$ phase contrast water-immersion objective (NA 1.2).

The non-visual Drosophila arrestin homolog, Kurtz, which exhibits significant sequence similarity with mammalian arrestins, functions similar to $\beta$-arrestin 2 in receptor regulation, and as such has been useful in the characterization of insect GPCR internalization (Yang et al., 2013, 2016). For arrestin translocation assays, a fluorescent chimera of Kurtz C-terminally tagged with the red fluorescent protein mCherry was constructed by overlap extension PCR (Wurch et al., 1998) using a cDNA clone (FBcl0171107; Drosophila Genomics Resource Center, Bloomington, IN) with chimeric primers (sense: 5'-GCTGAAACAGAGGCCATGGTGAGCAAGGGCGAG-3'; antisense: 5'-CTCGCCCTTGCTCACCATGGCCTCTGTTTCAGC-3') and gene specific primers (sense Drosophila Kurtz: 5'-CATAATGAACGGTGGTGGTG-3'; antisense mCherry: 5'-CTACTTGTACAGCTCGTC). PCR was performed using KOD Hot Start polymerase (EMD-Millipore, Billerica, MA) with thermocycler conditions consisting of $95^{\circ} \mathrm{C}$ for $2 \mathrm{~min}$ followed by 21 cycles at $95^{\circ} \mathrm{C}$ for $20 \mathrm{~s}$, $58^{\circ} \mathrm{C}$ for $10 \mathrm{~s}$, and $70^{\circ} \mathrm{C}$ for $15 \mathrm{~s}$ with a final 5 -min extension at $72{ }^{\circ} \mathrm{C}$. The second overlap extension reactions used aliquots of the initial reactions with a Kurtz-specific forward primer and the mCherry reverse primer. Thermocycler conditions consisted of $95^{\circ} \mathrm{C}$ for $2 \mathrm{~min}$ followed by 21 cycles at $95^{\circ} \mathrm{C}$ for $20 \mathrm{~s}, 58^{\circ} \mathrm{C}$ for $10 \mathrm{~s}$, and $70{ }^{\circ} \mathrm{C}$ for $45 \mathrm{~s}$ with a final 5 -min extension at $72{ }^{\circ} \mathrm{C}$. The resulting products were gel excised, treated with ExTaq DNA polymerase (Takara Bio USA, Mountain View, CA) to add 3'A overhangs, cloned into the $\mathrm{pIB} / \mathrm{V} 5-\mathrm{His}$ TOPO TA vector, and sequence verified. The resulting plasmid was co-transfected into Tni cells with the Mambr-PBANR-mVenus variants as described above. Translocation was assessed following $1 \mathrm{~h}$ at $4{ }^{\circ} \mathrm{C}$ with $1 \mu \mathrm{M}$ of either a synthetic fragment of the Drosophila melanogaster sex peptide (SP) corresponding to residues 21-36 (DromeSP ${ }_{21-36}$; United Peptide, Herndon, VA) or $1 \mu \mathrm{M}$ Mambr-PT (SLAYVQKVFENVEFVPRLamide, synthesized as described in Köblös et al., 2015). Cells were imaged as before on a Fluoview FV10i-LIV fluorescent confocal laser-scanning microscope. All confocal images were processed using Photoshop CS6 (Adobe Systems, San Jose, CA). To determine quantifiable differences in receptor internalization, the fluorescence attributable to internalized ligand relative to total cellular fluorescence (including plasma membrane fluorescence) was calculated in ImageJ using confocal image data collected in the red channel. Statistical analyses were performed using a one-way ANOVA with Tukey's multiple comparisons test in GraphPad Prism6 (GraphPad Software, San Diego, CA).

\subsection{Single-cell calcium imaging}

To examine Mambr-PBANR responsiveness to ligand activation, polyclonal Sf9 insect cell lines stably expressing each of the isoforms were generated. Briefly, the Mambr-PBANR variant coding sequences were cloned into the pIB/V5-His-TOPO TA insect expression vector and transfected as before into adherent Sf9 cells (Allele
Biotechnology). At $48 \mathrm{~h}$ post-transfection, cells were cultured in TNMFH media supplemented with $100 \mu \mathrm{g} / \mathrm{mL}$ blasticidin (InVivoGen, San Diego, CA) for three weeks and then maintained in TNMFH media supplemented with $10 \mu \mathrm{g} / \mathrm{mL}$ blasticidin. On the day of the experiment, 3-4 $\times 10^{5}$ polyclonal cells were seeded into a black-walled, clear bottom, tissue-culture treated 96-well microplate (Corning, Corning, NY). After attachment, cells were loaded with the calcium indicator, Fluo-4 using a Fluo-4 direct calcium assay kit (Thermo Fisher Scientific) diluted 1:1 with TNMFH. The cells were incubated in the dark for 60-90 min and then washed once with IPL-41 prior to ligand challenge in $60 \mu \mathrm{L}$ IPL41. Cell fluorescence measurements were taken every $8 \mathrm{~s}$ for $4 \mathrm{~min}$. The synthetic ligands Helze-PBAN (LSDDMPATPADQEMYRQDPEQIDSRTKYFSPRLamide,

Bachem Americas, Inc.; Torrance, CA) and Mambr-PT were added in a $15-\mu \mathrm{L}$ volume after $32 \mathrm{~s}$ and a final concentration of $10 \mu \mathrm{M}$ ionomycin (Thermo Fisher Scientific) added after $200 \mathrm{~s}$ as a calcium ionophore. Non-transfected Sf9 cells were likewise assayed. Fluorescence recordings were made using an FSX-100 fluorescence microscope (Olympus) with single cell measurements processed using the Fiji image processing package for Image J (Schindelin et al., 2012). Fluorescence values were calculated by subtracting both non-specific background fluorescence and the average fluorescence intensity over the first $32 \mathrm{~s}$ (i.e. basal cellular fluorescence pre-stimulation), and then expressed relative to the maximal value obtained following the addition of ionomycin. Dose-response curves were generated using GraphPad Prism6.

\subsection{Developmental and tissue $m R N A$ expression}

PGs from pupae and adult moths on the day of eclosion (day 0) or two days after eclosion (day 2), adult male aedaegus two days after emergence, and brains, legs and fat bodies of two-day-old females were dissected, immediately frozen in liquid nitrogen, and stored at $-70{ }^{\circ} \mathrm{C}$ until subsequent processing. Total RNA was extracted from the frozen tissues as well as second and fourth instars as described above (see Section 2.2). After DNase I treatment, first-strand cDNA synthesis was performed with $1 \mu \mathrm{g}$ total RNA using the High-Capacity cDNA Reverse Transcription kit (Applied Biosystems) and random hexamer primers.

Quantitative real-time PCR (qRT-PCR) analysis was performed to analyze the relative mRNA expression level in various tissues and developmental stages. We designed the sense 5'-GAGTGGGCAGATGCAGTACAG-3' and antisense 5'-GGGTTGATAGCGGTTGACAG-3' primer pair to amplify a 228-bp fragment (positions 753 to 980 relative to the translational start codon) of the three Mambr-PBANR-A, -B and -C variants. Three variant-specific primer pairs were also designed using Primer-BLAST. For PBANR-A, the sense 5'-TCTACTTGTATTGTGACCGCAGG-3' and antisense 5'-CAAAGAGGTCGACATGCTCCATCA-3' primers were used to amplify a 139-bp fragment (positions 1056 to 1194 relative to the translational start codon). A 336-bp (positions 1018-1353) fragment from the long variants (PBANR-B and -C) was amplified using long variant specific sense 5'-GCCTTCAAGGTGACGTTAGCGAC-3' and antisense 5'-GACTGGAGTTGGAGATGCTTCGAG-3' primers. A 153-bp PBANR-C fragment (positions 1201-1353) was amplified using the PBANR-C specific sense 5'-CCACGAGCGCAGGTGAGTG-3' primer and the long variant antisense primer. To ensure the specificity of PCR amplifications, qRT-PCR was performed using $1 \mathrm{ng}$ plasmid DNA containing the full-length sequence of each PBANR variant (PBANR-A, -B, or -C) as template with primer sets designed for specific amplification of each PBANR sequence.qRT-PCR was performed on a CFX96 Touch Real-Time PCR 
Detection System (Bio-Rad) using SensiFAST SYBR No-ROX kit (Bioline) in a $20-\mu \mathrm{l}$ reaction volume and running a standard program $\left(95^{\circ} \mathrm{C}\right.$ for $2 \mathrm{~min}, 40$ cycles at $95^{\circ} \mathrm{C}$ for $10 \mathrm{~s}, 60{ }^{\circ} \mathrm{C}$ for $10 \mathrm{~s}$ and $72{ }^{\circ} \mathrm{C}$ for $10 \mathrm{~s}$ ), followed by a melt curve analysis to determine amplicon specificity using a temperature range from $65{ }^{\circ} \mathrm{C}$ to $95{ }^{\circ} \mathrm{C}$ with increments of $0.5^{\circ} \mathrm{C}$. Levels of PBANR mRNAs were normalized to ribosomal protein L8 (rpl8, GenBank AY485337) mRNA levels. The primer pair designed to amplify a 159-bp fragment of rpl8 (from position 126 to 284) were sense 5'-GGGTGTCGTGAAGGACATCATC-3' and antisense 5'-GTAGCTTTCTTGCCGCAGTAGAC-3'. All reactions were performed using three technical replications from three biological replicates. In each run, water blank and non-reverse transcribed RNA were used as negative controls. Quantification was performed according to the standard curve method (Larionov et al., 2005) using serial dilutions of pooled PG cDNA. Real-time PCR efficiencies were $90,98,95,98$ and $100 \%$ for rp18, PBANR-A, $-\mathrm{C},-\mathrm{B}-\mathrm{C}$ and $-\mathrm{A}-\mathrm{C}$, respectively, with $\mathrm{r}^{2}=0.99$ or higher. The products were purified with a High Pure PCR product purification kit (Roche) and sequenced.

\section{Results}

\section{1. cDNA cloning}

Degenerate oligonucleotide primers designed to conserved nucleotide sequences in lepidopteran PBANRs facilitated RACE-based identification of cDNA clones encoding 356-aa, 477-aa and 470-aa proteins with 99, 97 and $97 \%$ identity to Psese-PBANR-A, -B and $-\mathrm{C}$, respectively. Therefore, the predicted sequences, each representing one of the three receptor subtypes were designated Mambr-
PBANR-A, -B and -C (Fig. 1). The three predicted Mambr-PBANRs share a common $\mathrm{N}$-terminal region of 343 amino acids with seven putative transmembrane domains. The Mambr-PBANR primary sequences contain two N-terminal consensus glycosylation sites, N19 and N22, and an ERY motif (aa 137-139) in transmembrane domain 3 . The $\mathrm{C}$-terminal extensions are predicted to form intracellular tails of varying size and sequence (Fig. 1). In addition, two consensus protein kinase C serine phosphorylation sites (residues S334 and S366) were predicted in the $\mathrm{C}$ terminus. The $\mathrm{C}$-terminal domains of the longer Mambr-PBANRs also contain a third potential phosphorylation site, S361 that flanks the tyrosine in a putative YXXФ endosomal targeting motif (Fig. 1). Mambr-PBANR-C contains a 5-nt insertion at nt 1210 resulting in a frameshift that introduces a stop codon (TGA) at amino acid position 470 (Fig. 1). The shorter PBANR-A variant may also result from alternative splicing of the $3^{\prime}$ coding region. Sequence analysis revealed that the $\sim 400$-bp part of the coding sequence unique to the PBANR-B and-C variants is GC-rich (67-68\%). In contrast, the 43-bp C-terminal coding sequence unique to PBANR-A is AT-rich (the GC-content is $23 \%$ ).

Sequence alignment of the Mambr-PBANRs with other PBANR sequences was used to assess phylogenetic relationships by the maximum-likelihood method (Fig. 2). All three Mambr-PBANRs clustered with high bootstrap support with PBANR sequences from other noctuid species including Spodoptera littoralis (Zheng et al., 2007), $H$. virescens (Kim et al., 2008), S. exigua (Cheng et al., 2010), Pseudaletia separata, H. zea, H. armigera (Lee et al., 2012) and Agrotis segetum (Ding and Löfstedt, 2015). Furthermore, all of the receptors clustered in species specific clades. Similar to Nusawardani et al. (2013), the Plutellidae sequence was basal to the other PBANRs.

\section{TM1}

PBANR-A MTLPVPPSIDEYEDPFVMNTTNVTSHPAAYDEQYALDLVVPLTVTYVVIFVAGILGNTSTCVVIARNRSMHTATN 75 PBANR-B MTLPVPPSIDEYEDPFVMNTTNVTSHPAAYDEQYALDLVVPLTVTYVVIFVAGILGNTSTCVVIARNRSMHTATN 75 PBANR-C MTLPVPPSIDEYEDPFVMNTTNVTSHPAAYDEQYALDLVVPLTVTYVVIFVAGILGNTSTCVVIARNRSMHTATN 75

TM2

TM3

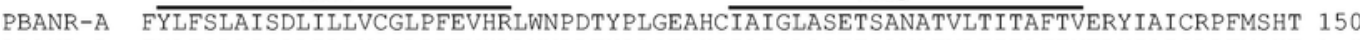
PBANR-B FYLFSLAISDLILLVCGLPFEVHRLWNPDTYPLGEAHCIAIGLASETSANATVLTITAFTVERYIAICRPFMSHT 150 PBANR-C FYLFSLAISDLILLVCGLPFEVHRLWNPDTYPLGEAHCIAIGLASETSANATVLTITAFTVERYIAICRPFMSHT 150

\section{TM4}

\section{TM5}

PBANR-A MSKLSRAVRFIIAIWVVALCTAVPQAMQF GIVSYVDNGQNVSACTVKGVGVHQVFVISSFVFFVVPMSMISVLYA 225 PBANR-B MSKLSRAVRFIIAIWVVALCTAVPQAMQFGIVSYVDNGQNVSACTVKGVGVHQVFVISSFVFFVVPMSMISVLYA 225 PBANR-C MSKLSRAVRFIIAIWVVALCTAVPQAMQFGIVSYVDNGQNVSACTVKGVGVHQVFVISSFVFFVVPMSMISVLYA 225

\section{TM6}

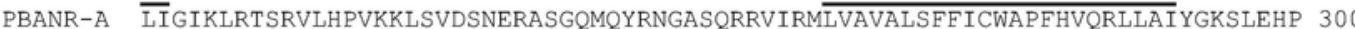
PBANR-B LIGIKLRTSRVLHPVKKLSVDSNERASGQMQYRNGASQRRVIRMLVAVALSFFICWAPFHVQRLLAIYGKSLEHP 300 PBANR-C LIGIKLRTSRVLHPVKKLSVDSNERASGQMQYRNGASQRRVIRMLVAVALSFFICWAPFHVQRLLAIYGKSLEHP 300

\section{TM7}

PBANR-A SDTFYLVYIVLTFLSGVIYFISTAINPFIYNIMSNKFRNAFKVRECNIFMIDLLVI

PBANR-B SDTFYLVYIVLTFLSGVLYFLSTAINPFLYNIMSNKFRNAFKVTLATWCGRGGPRMGRT YSAT IASQRLRAGGPG 375 PBANR-C SDTFYLVYIVLTFLSGVLYFLSTAINPFLYNIMSNKFRNAFKVTLATWCGRGGPMGRIYSAI IASQRLRAGGPG 375

PBANR-B ACASVRGTRRLRRLSTATTQLYDAPPRAQCYNGRDLPTVNESPSGNGHWARAWRLRIHDPSDSVDSPRSISNSSI 450 PBANR-C ACASVRGTRRLRRLSTATTQLYDAPPRAQVSATTGAIYQPLTSPRAGMGTGLARGVEGSTTPPTPSTPLEASPTP 450

PBANR-B REVDDELTGEELATYMYHVNCNIGGLT

PBANR-C VFARSTTNSPARSWPPTCTT

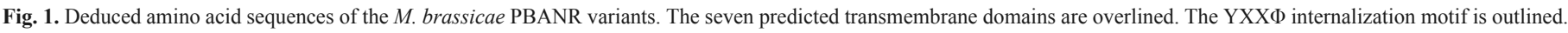
Residues unique to the PBANR variants are shaded grey. 


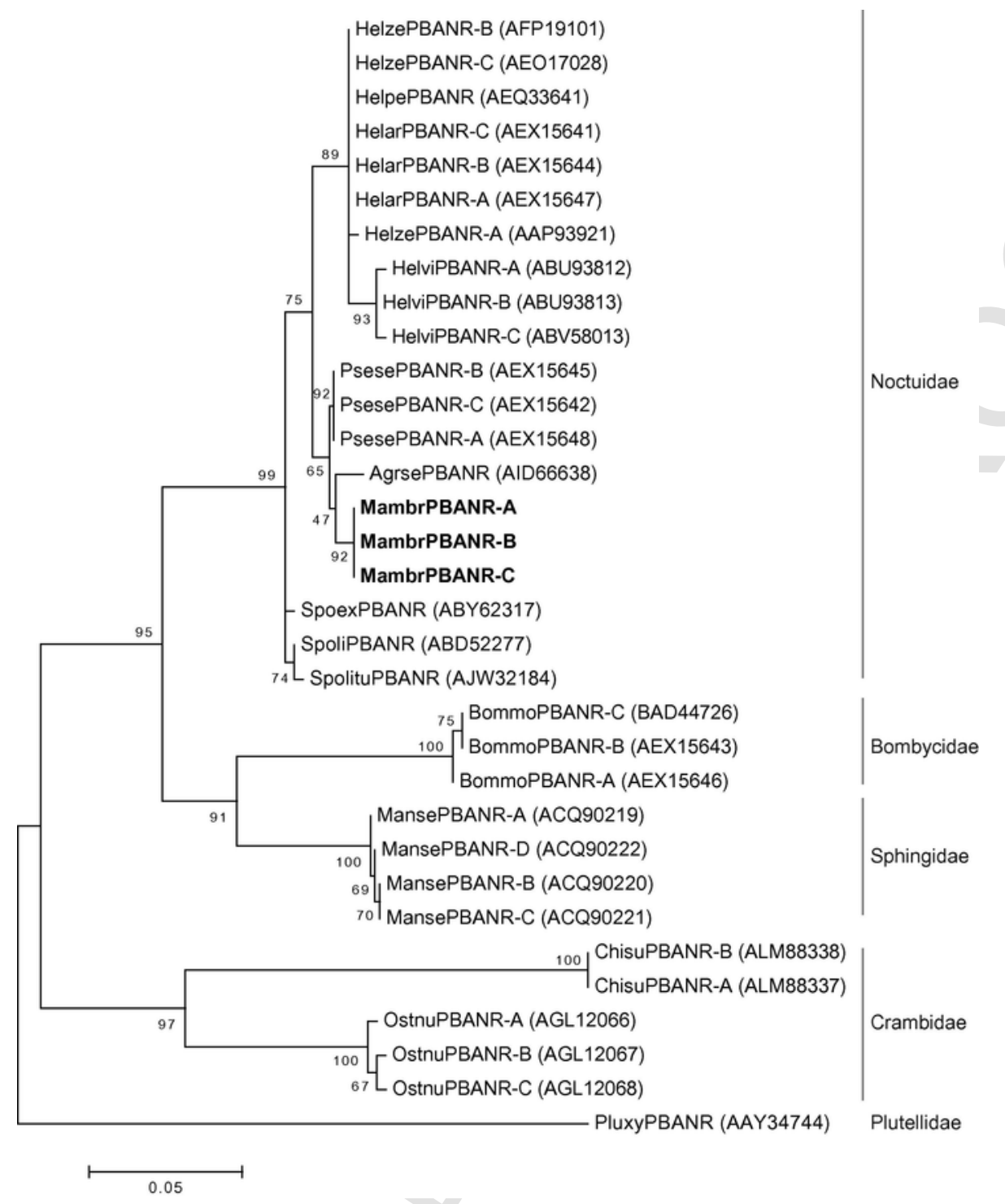

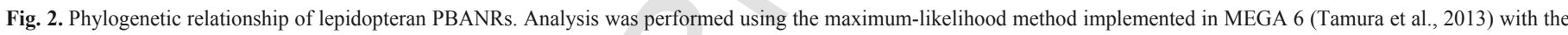

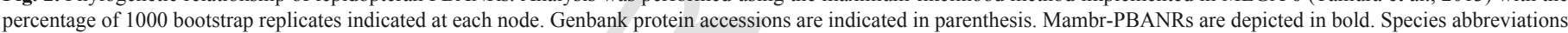

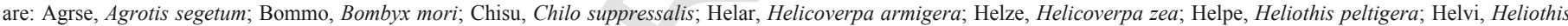

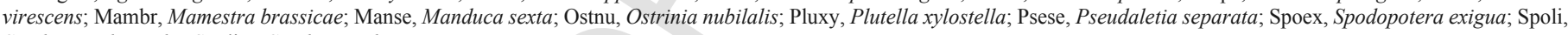
Spodoptera littoralis; Spolitu, Spodoptera litura.

\subsection{Cellular localization and ligand-induced internalization}

To examine the cellular localization of the three Mambr-PBANR isoforms, each was C-terminally tagged with the fluorescent protein mVenus and transiently expressed in cultured Tni cells. Confocal microscopy revealed fluorescent signals associated with the plasma membrane of transfected cells for all three isoforms (Fig. 3A). This localization, however, was not exclusive as intracellular fluorescence was also detected, suggesting incomplete or impaired trafficking of the respective isoforms either as a result of overexpression or an artifact of the chimeric constructs.

To determine if the Mambr-PBANR isoforms undergo ligand-induced receptor internalization, cells transiently expressing the chimeric receptors were incubated with a rhodamine red-labeled PBAN derivative (RR-10CPBAN) and then imaged immediately after incubation and 15 min post-incubation. Initially, red fluorescence was observed at the cell surface where it co-localized with the chimeric PBANR fluorescence signals, suggesting receptor-ligand interaction. No fluorescence was observed in non-transfected cells (data not shown). Time-course imaging of the same cells revealed intracellular accumulation of red fluorescent punctae that co-localized with green fluorescent signals in cells expressing the Mambr-PBANR-B and -C isoforms but not the shorter-A isoform (Fig. 3A; right panel). The percentage RR-10CPBAN internalized was significantly higher (45-48\% $v s . \sim 22 \%$ ) in cells expressing the longer Mambr-PBANR isoforms as compared to the shorter Mambr-PBANR-A (Fig. 3B). 
(A)

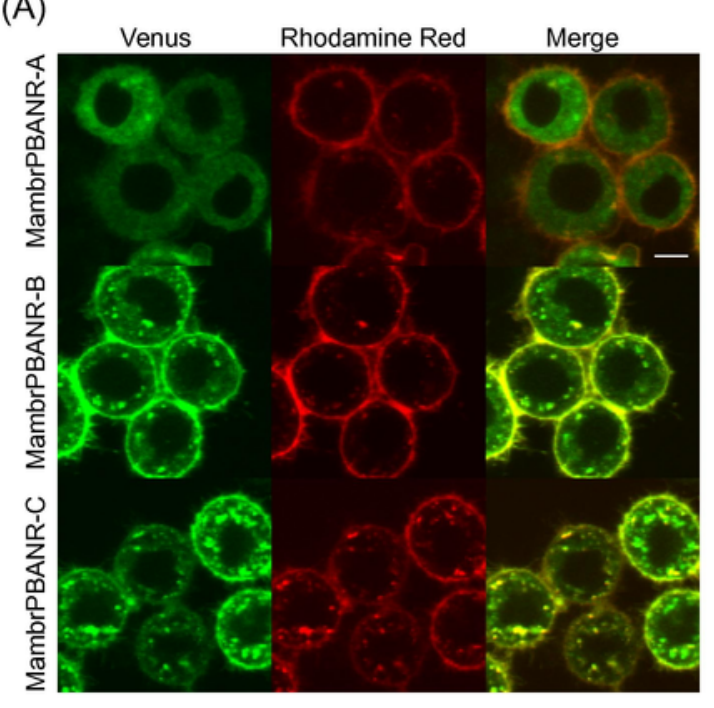

0 min post-incubation

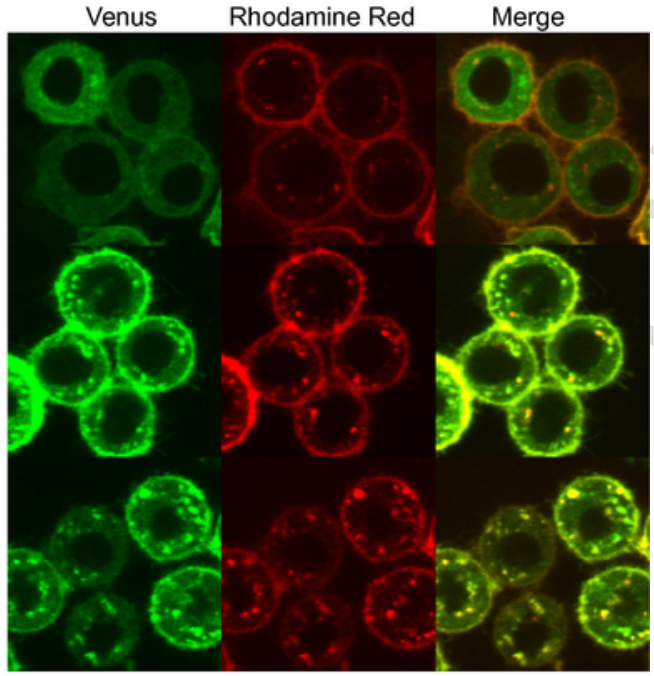

15 min post-incubation

(B)

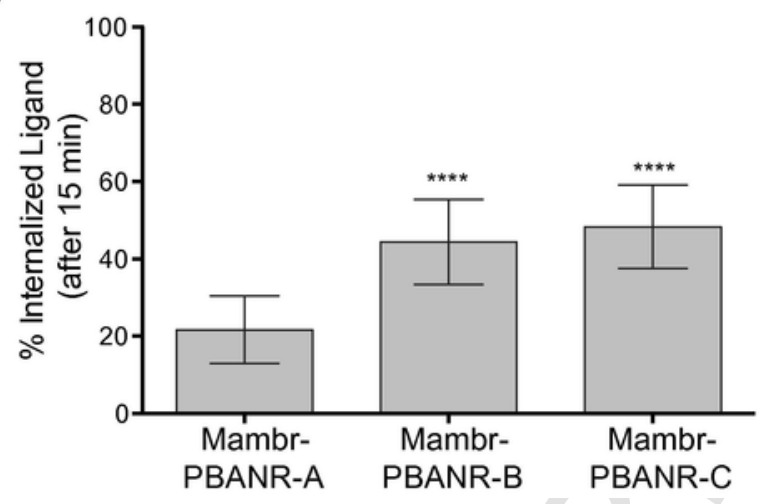

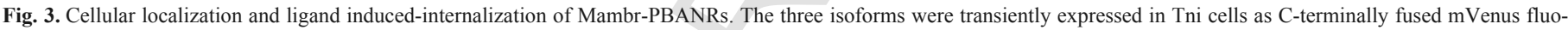

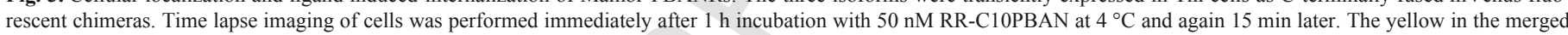

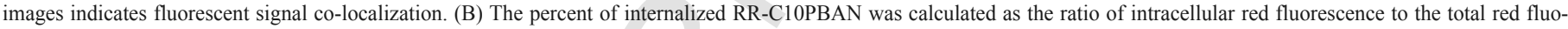

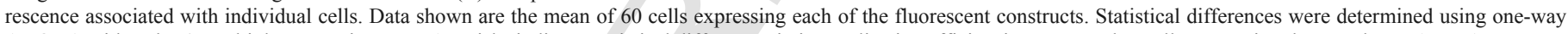

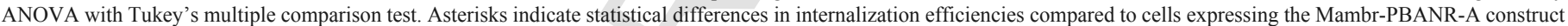
$(\mathrm{P}<0.0001)$.

\subsection{Ligand-induced translocation of the Drosophila arrestin homolog, Kurtz}

To assess the role of arrestins in the internalization of the Mambr-PBANR isoforms, we constructed a fluorescent chimera of the non-visual Drosophila arrestin, Kurtz (DromeKurtz), fused at its C-terminus with the red fluorescent protein, mCherry, and co-transfected it with the respective PBANR variants. Consistent with previous reports (Yang et al., 2013, 2016), DromeKurtz-mCherry localization was cytosolic in the absence of ligand stimulation (data not shown). Incubation with $1 \mu \mathrm{M}$ Mambr-PT induced partial translocation of the Kurtz construct to the cell surface and/or co-localization with internalized receptors in cells expressing the Mambr-PBANR-B and -C isoforms (Fig. 4; merged panels). Translocation was ligand-dependent as incubation with $1 \mu \mathrm{M}$ of an unrelated peptide $(D$. melanogaster SP residues 21-36; DromeSP ${ }_{21-36}$ ), which lacks the pheromonotropic FXPRL-amide motif, had no effect on Kurtz localization (Fig. 4). Consistent with the lack of ligand-induced internalization detailed above, we observed no ligand-induced translocation or co-localization of DromeKurtz-mCherry in cells co-expressing Mambr-PBANR-A.

\subsection{Functional expression and characterization in cultured insect cells}

To assess the functionality of the three Mambr-PBANR isoforms in terms of $\mathrm{Ca}^{2+}$ signaling, each isoform was stably expressed in Sf9 insect cells and receptor activation monitored by single cell fluorescent $\mathrm{Ca}^{2+}$ imaging. Cells expressing the Mambr-PBANR-C isoform exhibited a dose-dependent fluorescence response following the addition of varying concentrations of synthetic Helze-PBAN (Fig. 5A). No response was observed in non-transfected Sf9 cells following addition of $5 \mu \mathrm{M}$ Helze-PBAN, suggesting that $\mathrm{Ca}^{2+}$ mobilization in the 

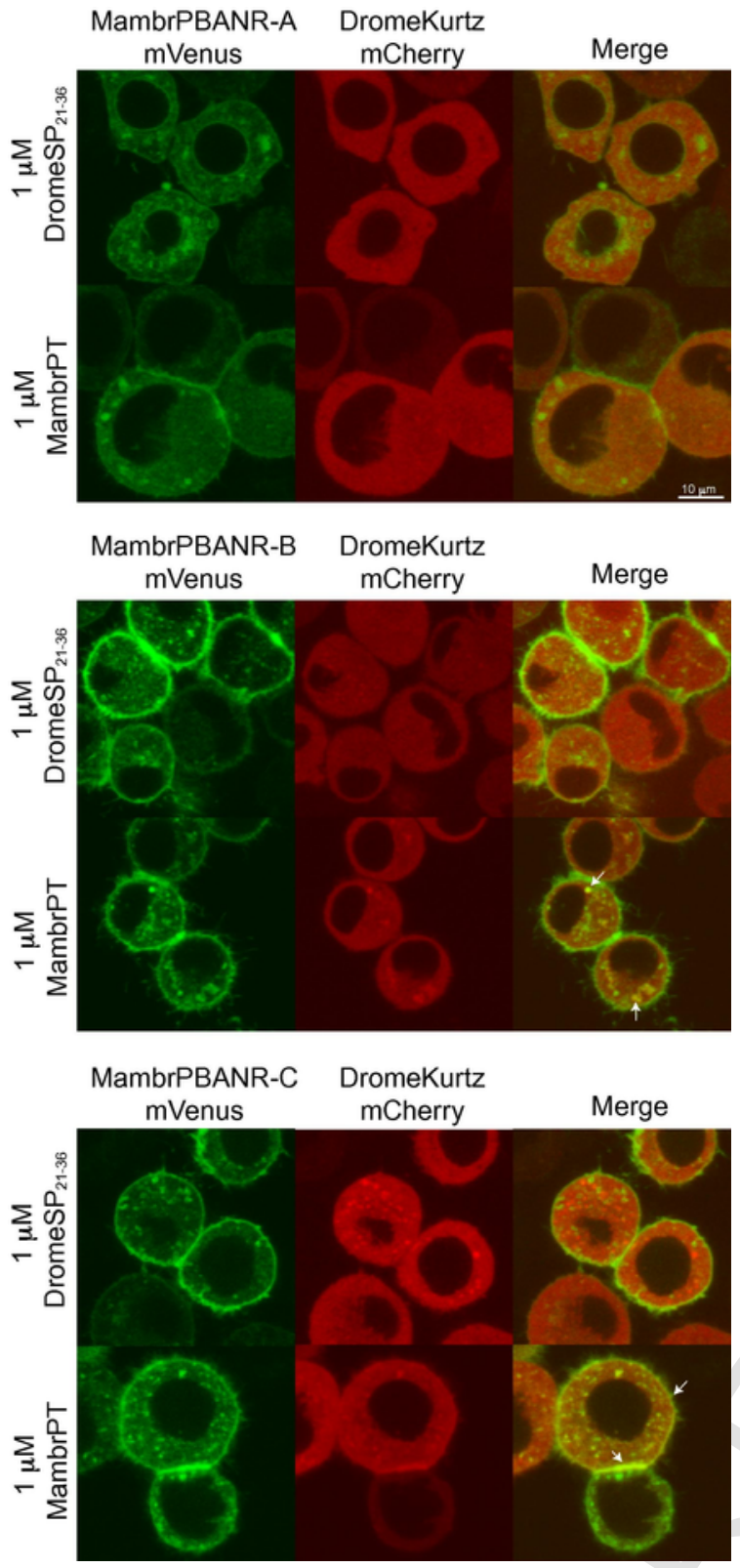

Fig. 4. Ligand-induced translocation of a chimeric arrestin homolog. Tni cells transiently co-expressing mVenus constructs of the Mambr-PBANR isoforms with DromeKurtz-mCherry. Cells were incubated for $1 \mathrm{~h}$ with $1 \mu \mathrm{M}$ of either Mambr-PT or DromeSP ${ }_{21-36}$ at $4{ }^{\circ} \mathrm{C}$ and then imaged 15 min post-incubation on a confocal scanning laser microscope. Arrows indicate regions of fluorescent signal co-localization consistent with an arrestin-PBANR interaction.

polyclonal line was specific to the expressed transgene. Similarly, no increase in fluorescence (Fig. 5A) was observed in the Mambr-PBANR-C cell line following the addition of $5 \mu \mathrm{M}$ DromeSP $21-36$, indicating that receptor activation is ligand specific.

Synthetic Helze-PBAN generated dose-dependent fluorescent $\mathrm{Ca}^{2+}$ responses in all three Mambr-PBANR cell lines with greatest activity $\left(\mathrm{EC}_{50}\right.$ value of $\left.26 \mathrm{nM}\right)$ in the Mambr-PBANR-C line (Fig. $\left.5 \mathrm{~B}\right) . \mathrm{EC}_{50}$ values in the Mambr-PBANR-A and Mambr-PBANR-B cell lines were comparable (48 $\mathrm{nM}$ and $42 \mathrm{nM}$, respectively). Dose-dependent stimulation was also observed with synthetic Mambr-PT (Fig. 5B), which was equally potent in the Mambr-
PBANR-B $\left(\mathrm{EC}_{50} \sim 63 \mathrm{nM}\right)$ and Mambr-PBANR-C $\left(\mathrm{EC}_{50} \sim 69 \mathrm{nM}\right)$ lines, but was 2-fold less active $\left(\mathrm{EC}_{50} \sim 147 \mathrm{nM}\right)$ in the Mambr-PBANR-A line. The lowest concentration of ligand to generate a $\mathrm{Ca}^{2+}$ response was $1 \mathrm{nM}$ Helze-PBAN in the Mambr-PBANR-C line.

\section{5. qPCR-based expression profiling}

Expression of Mambr-PBANR transcripts was determined in immature and adult stages of $M$. brassicae. The transcript abundance of each variant was determined by qRT-PCR and normalized to the expression levels of rpl8 mRNA. Compared to PBANR-A, we observed significantly higher $(P<0.05)$ transcript levels of the PBANR-B and $-\mathrm{C}$ variants in the PG extracts (Fig. 6). Analysis of the expression pattern in PGs revealed higher $(P<0.05)$ levels of PBANR-B and $-\mathrm{C}$ transcripts in 2-day-old females as compared to pre-emergence pupae. Our data also showed that the mRNA expression of the three PBANR subtypes was generally low in other tissues (Fig. 6). No appreciable expression of Mambr-PBANR was detected in leg muscles or fat bodies (data not shown).

\section{Discussion}

Here we report on the molecular cloning and functional characterization of $M$. brassicae PBANRs. Three variants (PBANR-A, -B, and -C) that exhibit high sequence homology with noctuid moth PBANRs were identified in female $M$. brassicae PGs. The expression of multiple PBANRs appears to be a conserved feature in moths with variants reported in six species representing three families (Noctuidae, Sphingidae, and Bombycidae; Lee et al., 2012). Alternative splicing of GPCR transcripts, which is one of the principal means by which organisms generate functional protein diversity in a temporal- and/or tissue-dependent manner, has been extensively documented (Markovic and Challiss, 2009; Minneman, 2001). In B. mori, the PBANR gene spans six exons and five introns with the variable $C$ terminus encoded on exons 5-6 (Lee et al., 2012). The short Bommo-PBANR variants (PBANR-As and PBANR-A) are generated following retention of a spliced intron. The longer variants arise from conventional splicing of exons 2-6 (PBANR-B) or a five-nucleotide insertion in exon 5 that introduces a stop codon in the middle of the C-terminal coding sequence (PBANR-C) (Lee et al., 2012). Mambr-PBANR-C likewise arises from a 5-nt insertion that introduces a stop codon in the C-terminal sequence, suggesting that the PBANR splicing mechanism may be conserved across species.

The biological significance underlying expression of multiple PBANRs in moth PGs remains to be determined. One possibility is that the isoforms provide a mechanism for fine-tuning cellular responsiveness to the pheromonotropic signal. Truncated isoforms of some mammalian receptors have been shown to exert dominant negative effects on signaling when co-expressed with more highly expressed isoforms (Chow et al., 2012; Seck et al., 2005; Zmijewski and Slominski, 2009). Alternatively, the multiple PBANR transcripts may reflect a spatio-temporal dependence of functionality. This hypothesis is especially attractive given the pleiotropic complexity of PBAN, the multiplicity of reports detailing PBANR activation by multiple FXPRL-amide peptides (Choi et al., 2003; Hariton-Shalev et al., 2013; Kim et al., 2008; Shalev and Altstein, 2015; Watanabe et al., 2007), and the varied tissue/developmental expression profile of PBANR transcripts. In $M$. brassicae, we detected the mRNA expression of each receptor variant in all life stages. Similar to other reports (Lee et al., 2012; Nusawardani et al., 2013), PBANR-A was expressed at lower levels in PGs of adult females compared to the long variants. The long variant receptor transcripts were more robustly ex- 


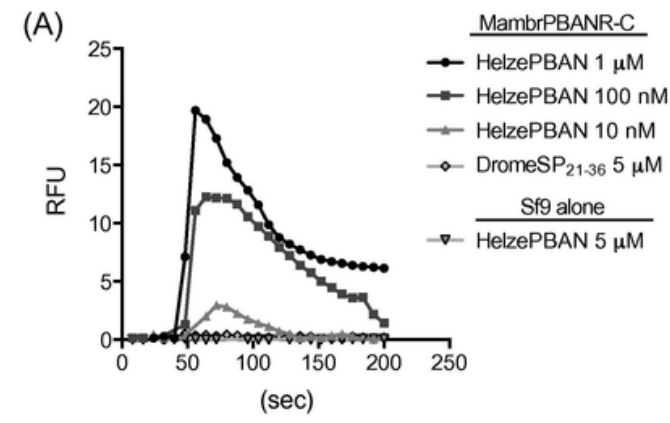

(B)

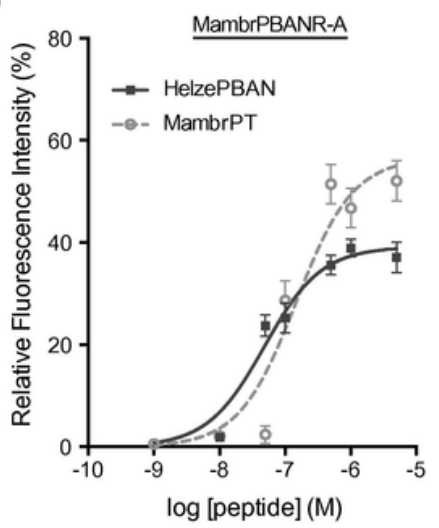

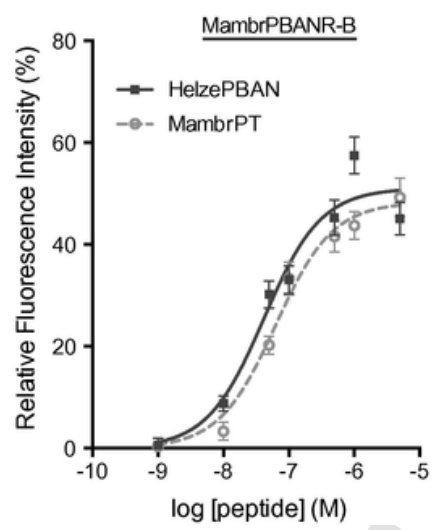

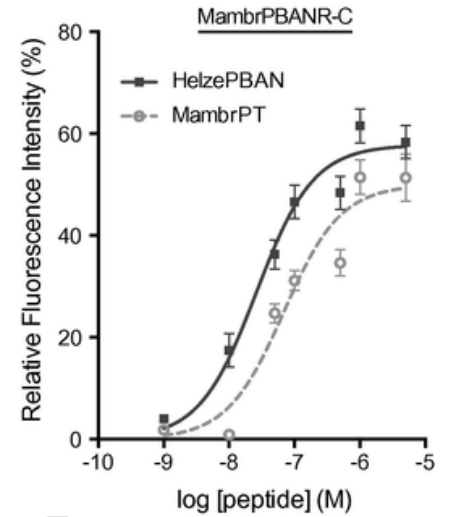

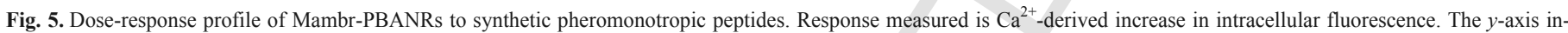

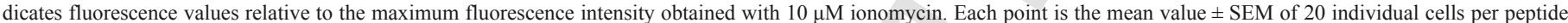

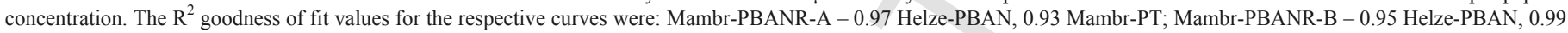
Mambr-PT; and Mambr-PBANR-C - 0.97 Helze-PBAN, 0.93 Mambr-PT.

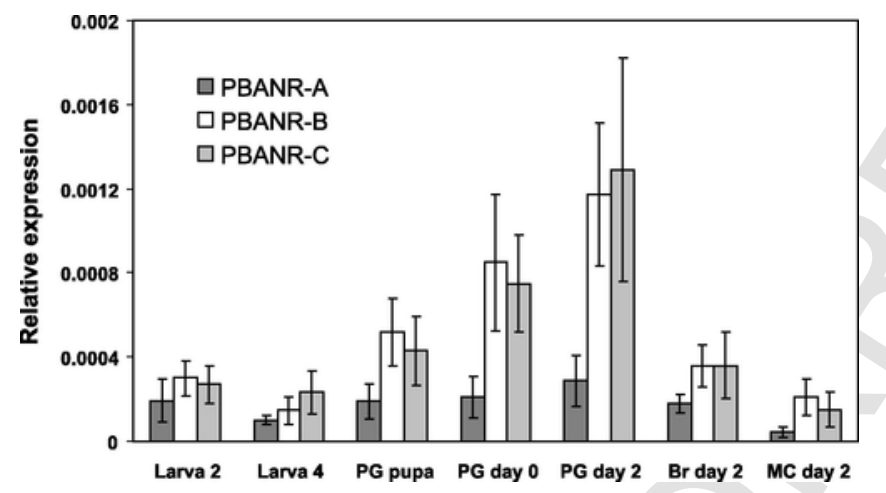

Fig. 6. Relative expression levels of the Mambr-PBANR variants. qRT-PCR was performed using larvae, pheromone glands $(\mathrm{PG})$ and brain $(\mathrm{Br})$ tissue of females, and hair-pencil-aedeagus complexes of males (MC). Each sample was pooled from five specimens. PGs were dissected from pupae and adult moths on the day of eclosion (day 0 ) or two days after eclosion (day 2). Expression levels are presented as relative to the control gene rpl8 with error bars representing standard deviations from at least three independent replicates.

pressed in PGs of adult females and at lower levels in female brain and hair-pencil aedeagus complexes of adult males. These results are in agreement with earlier studies reporting PBANR transcripts in hair-pencil-aedeagus complex of adult $H$. armigera males (Rafaeli et al., 2007), silencing of which resulted in a decreased production of male hair-pencil components (Bober and Rafaeli, 2010). Expression of PBANR has also been reported for the nerve cord and brain in $B$. mori, H. armigera and Ostrinia nubilalis (Nusawardani et al., 2013; Rafaeli et al., 2007; Watanabe et al., 2007). The varied spatial expres- sion of PBANR transcripts suggests a pleiotropic role for the receptor in mediating diverse biological functions in Lepidoptera.

Similar to Helze-PBANR and Bommo-PBANR (Choi et al., 2003; Hull et al., 2004), two N-terminal consensus glycosylation sites, N19 and N22 were identified in M. brassicae (Fig. 1). Site-directed replacement of these sites in the Helze-PBANR N terminus negatively affected PBAN-stimulated $\mathrm{Ca}^{2+}$ influx (Choi et al., 2007), whereas in Bommo-PBANR loss of those sites via N-terminal truncations had little effect on cell surface localization or ligand-induced internalization (Hull et al., 2011). Given the phylogenetic relatedness of the Mambr-PBANRs with the Helze-PBANR (both members of the Noctuidae family), it will be interesting to ascertain what role $\mathrm{N}$-glycosylation may have in their function. Our results also support previous findings regarding the highly conserved nature of the 3 rd extracellular loop (Fig. 1), which was found to be essential for ligand binding (Choi et al., 2007). Extracellular loop 3 has been implicated in peptide ligand-GPCR interactions (Gether et al., 2002; Peeters et al., 2011) and contributes to the overall stabilization of the ligand binding pocket (Choi and Jurenka, 2010). In addition, two consensus protein kinase $\mathrm{C}$ serine phosphorylation sites (residues S334 and S366) were predicted in the $\mathrm{C}$ terminus. The $\mathrm{C}$-terminal domains of two of the Mambr-PBANRs also contain a third potential phosphorylation site, S361 that flanks the tyrosine comprising a portion of a putative YXXФ endosomal targeting motif critical in internalization of the Bommo-PBANR (Hull et al., 2005). It should be noted that S366 and the YXXФ motif are absent in Mambr-PBANR-A.

For most vertebrate GPCRs, receptor activation triggers a signal transduction cascade that culminates in feedback regulation of the receptor via rapid endocytotic removal from the cell surface. This regulatory mechanism thus modulates the duration and intensity of the re- 
ceptor-mediated signal transduction cascade (Hanyaloglu and Zastrow, 2008). Although ligand-induced internalization has been extensively studied in mammalian systems, the GPCRs that have been similarly characterized in insects are limited to the $B$. mori adipokinetic hormone (AKH) receptor (Huang et al., 2011), the B. mori corazonin receptor (Yang et al., 2013, 2016), the Drosophila SP receptor (Hull and Brent, 2014), and three moth PBANRs (Hull et al., 2004, 2005, 2011; Kawai et al., 2014; Lee et al., 2012). In each study, the respective receptor exhibited rapid internalization in mammalian and/ or insect cell lines following addition of labeled and unlabeled cognate ligands. Our demonstration that two of the three Mambr-PBANR isoforms likewise undergo endocytotic removal from the cell surface in tandem with bound ligand (Fig. 3A) extends previous studies on the regulatory mechanism underlying PBANR regulation and further supports functional differentiation of the short and long PBANRs. The less robust internalization observed for the Mambr-PBANRs ( $\sim 45-48 \%$ ) compared to the $\sim 90 \%$ reported for the other moth PBANRs (Hull et al., 2004, 2005, 2011; Kawai et al., 2014; Lee et al., 2012) may be due to differences in the fluorescent protein used (Venus vs. EGFP) and/or differences in the cell expression system (Tni vs. Sf9). The reduced internalization observed in cells expressing the Mambr-PBANR-A construct, however, is consistent with that reported in cells expressing "short" PBANRs from other moths. The endocytotic removal of GPCRs from the cell surface is typically mediated by $\beta$-arrestins (Moore et al., 2007; Smith and Rajagopal, 2016). For insect GPCRs, both $\beta$-arrestin 2 and the non-visual arrestin, Kurtz, have been shown to facilitate receptor internalization (Huang et al., 2011; Yang et al., 2013). Internalization of PBANRs likely also proceeds through an arrestin-dependent pathway as Mambr-PBANR activation recruited a fluorescent chimera of Kurtz to the cell surface (Fig. 5) and co-localization of the respective fluorescent signals post-endocytosis suggests persistence of the receptor-arrestin association (Fig. 4).

PBANR activation triggers an influx of extracellular $\mathrm{Ca}^{2+}$ response both in vivo and in vitro (Choi et al., 2003; Choi and Jurenka, 2006; Hull et al., 2004, 2007b). Heterologously expressed Mambr-PBANRs likewise dose-dependently mobilized $\mathrm{Ca}^{2+}$ in response to PBAN activation (Fig. 5). However, the receptors exhibited differing ligand sensitivities with Mambr-PBANR-C most sensitive to Helze-PBAN stimulation but less so ( 2.5-fold difference in $\mathrm{EC}_{50}$ value) to Mambr-PT (a $\beta$-SNGP). Similar differences were observed for the other two isoforms even though both ligands assayed contain the essential C-terminal FXPRL-amide motif and both are products of post-translational processing of the PBAN prepropeptide. Similar disparity in ligand potency was reported in the initial characterization of the $H$. zea PBANR (since shown to be the short A isoform) with the $\alpha$-SNGP (PGN-8) nearly 10-fold less active than the other FXPRL-amides in Sf9 cell-based fluorescent $\mathrm{Ca}^{2+}$ assays (Choi et al., 2003). Shalev and Altstein (2015) also reported differences in dose-response profiles of the H. peltigera and S. littoralis PBANRs, which share highest similarity with the short isoform receptors, to PBAN and $\beta$-SNGP in Sf9 cell-based fluorescent $\mathrm{Ca}^{2+}$ assays. Functional analysis of the B. mori PBANR-C isoform in Xenopus oocytes also indicated a difference albeit with PBAN $\sim 15$-fold less active than $\beta$-SNGP (Watanabe et al., 2007). Surprisingly, the $H$. virescens PBANR-A and -B isoforms exhibited little to no response to PBAN in mammalian cell-based $\mathrm{Ca}^{2+}$ assays (Kim et al., 2008). Because synthetic peptides of each have been reported to exhibit pheromonotropic activity (Ma et al., 1996) and the presence of the proteolytically processed peptide products in the SEG has been biochemically confirmed (Ma et al., 2000; Sato et al., 1994), the biological significance of these reported receptor activation differences is of great interest. A simple explanation is that the differences arise from the various receptor activation assays used. While that can explain cross-platform variation, it does not address the ligand selectivity observed in receptors that have essentially identical ligand binding pockets. Regardless, our identification and demonstration of receptor activation via fluorescent $\mathrm{Ca}^{2+}$ responses expand not only our understanding of sex pheromone biosynthesis in M. brassicae but also our model of PBANR function.

\section{Acknowledgments}

This work was supported by Hungarian Research Funds NKFIH (OTKA) K100421, K104011, and French-Hungarian collaborative agreement (Campus France PHC Balaton $\mathrm{N}^{\circ}$ 32064QF/ TÉT_12_FR-2-2014-0009). The authors acknowledge the contribution of the Drosophila Genomics Research Center (supported by NIH grant 2P40OD010949-10A1) and thank Gyöngyi Vajdics for excellent technical assistance as well as three anonymous reviewers for helpful comments to improve the manuscript. Mention of trade names or commercial products in this article is solely for the purpose of providing specific information and does not imply recommendation or endorsement by the U. S. Department of Agriculture. USDA is an equal opportunity provider and employer.

\section{References}

Altstein, M., Ben-Aziz, O., Bhargava, K., Li, Q., Martins-Green, M., 2003. Histochemical localization of the PBAN receptor in the pheromone gland of Heliothis peltigera. Peptides 24, 1335-1347.

Altstein, M., Hariton A., Nachman R., 2013. FXPRLamide (Pyrokinin/PBAN) family. In: Handbook of Biologically Active Peptides, pp. 255-266.

Blomquist, G., Vogt, R.G. (Eds.), 2003. Insect Pheromone Biochemistry and Molecular Biology. Elsevier, Academic Press, San Diego.

Blomquist, G.J., Jurenka, R., Schal, C., Tittiger, C., 2011. Pheromone production: biochemistry and molecular biology. In: Gilbert, L. (Ed.), Insect Endocrinology. Academic Press, pp. 523-567.

Bober, R., Rafaeli, A., 2010. Gene-silencing reveals the functional significance of pheromone biosynthesis activating neuropeptide receptor (PBAN-R) in a male moth. Proc. Natl. Acad. Sci. U.S.A. 107, 16858-16862.

Cheng, Y., Luo, L., Jiang, X., Zhang, L., Niu, C., 2010. Expression of pheromone biosynthesis activating neuropeptide and its receptor (PBANR) mRNA in adult female Spodoptera exigua (Lepidoptera: Noctuidae). Arch. Insect Biochem. Physiol. 75, 13-27.

Choi, M.Y., Jurenka, R.A., 2006. Role of extracellular $\mathrm{Ca}^{2+}$ and calcium channel activated by a $\mathrm{G}$ protein-coupled receptor regulating pheromone production in Helicoverpa zea (Lepidoptera: Noctuidae). Ann. Entomol. Soc. Am. 99, 905-909.

Choi, M.Y., Jurenka, R.A., 2010. Site-directed mutagenesis and PBAN activation of the Helicoverpa zea PBAN-receptor. FEBS Lett. 584, 1212-1216.

Choi, M.-Y., Fuerst, E.-J., Rafaeli, A., Jurenka, R., 2003. Identification of a G protein-coupled receptor for pheromone biosynthesis activating neuropeptide from pheromone glands of the moth Helicoverpa zea. Proc. Natl. Acad. Sci. U.S.A. 100, 9721-9726.

Choi, M.Y., Fuerst, E.J., Rafaeli, A., Jurenka, R., 2007. Role of extracellular domains in PBAN/pyrokinin GPCRs from insects using chimera receptors. Insect Biochem. Mol. Biol. 37, 296-306.

Chow, K.B.S., Sun, J., Chu, K.M., Cheung, W.T., Cheng, C.H.K., Wise, H., 2012. The truncated ghrelin receptor polypeptide (GHS-R1b) is localized in the endoplasmic reticulum where it forms heterodimers with ghrelin receptors (GHS-R1a) to attenuate their cell surface expression. Mol. Cell. Endocrinol. 348, 247-254.

Ding, B.J., Löfstedt, C., 2015. Analysis of the Agrotis segetum pheromone gland transcriptome in the light of sex pheromone biosynthesis. BMC Genomics 16, 711.

Fónagy, A., Teal, P., Meredith, J., Körmendy, C., Tumlinson, J., 1998. Partial identification of a new pheromonotropic peptide from Mamestra brassicae. Ann. N. Y. Acad. Sci. 839, 488-490.

Fónagy, A., Marco, H.G., König, S., Gäde, G., 2008. Biological activity and identification of neuropeptides in the neurosecretory complexes of the cabbage pest insect, Mamestra brassicae (Noctuidae; Lepidoptera). Acta Biol. Hung. 59, 385-402.

Gether, U., Asmar, F., Meinild, A.K., Rasmussen, S.G.F., 2002. Structural basis for activation of G-protein-coupled receptors. Pharmacol. Toxicol. 91, 304-312. 
Hanyaloglu, A.C., Zastrow, M.V., 2008. Regulation of GPCRs by endocytic membrane trafficking and its potential implications. Annu. Rev. Pharmacol. Toxicol. 48, 537-568.

Hariton-Shalev, A., Shalev, M., Adir, N., Belausov, E., Altstein, M., 2013. Structural and functional differences between pheromonotropic and melanotropic PK/PBAN receptors. Biochim. Biophys. Acta 1830, 5036-5048.

Hewes, R.S., Taghert, P.H., 2001. Neuropeptides and neuropeptide receptors in the Drosophila melanogaster genome. Genome Res. 11, 1126-1142.

Huang, H., Deng, X., He, X., Yang, W., Li, G., Shi, Y., Shi, L., Mei, L., Gao, J., Zhou, N., 2011. Identification of distinct c-terminal domains of the Bombyx adipokinetic hormone receptor that are essential for receptor export, phosphorylation and internalization. Cell Signal. 23, 1455-1465.

Hull, J.J., Brent, C.S., 2014. Identification and characterization of a sex peptide receptor-like transcript from the western tarnished plant bug Lygus hesperus. Insect Mol. Biol. 23, 301-319.

Hull, J.J., Ohnishi, A., Moto, K., Kawasaki, Y., Kurata, R., Suzuki, M.G., Matsumoto, S., 2004. Cloning and characterization of the pheromone biosynthesis activating neuropeptide receptor from the silkmoth, Bombyx mori. Significance of the carboxyl terminus in receptor internalization. J. Biol. Chem. 279, 51500-51507.

Hull, J.J., Ohnishi, A., Matsumoto, S., 2005. Regulatory mechanisms underlying pheromone biosynthesis activating neuropeptide (PBAN)-induced internalization of the Bombyx mori PBAN receptor. Biochem. Biophys. Res. Commun. 334, 69-78.

Hull, J.J., Kajigaya, R., Imai, K., Matsumoto, S., 2007. The Bombyx mori sex pheromone biosynthetic pathway is not mediated by cAMP. J. Insect Physiol. 53, 782-793.

Hull, J.J., Kajigaya, R., Imai, K., Matsumoto, S., 2007. Sex pheromone production in the silkworm, Bombyx mori is mediated by store-operated $\mathrm{Ca}^{2+}$ channels. Biosci. Biotechnol. Biochem. 71, 1993-2001.

Hull, J.J., Lee, J.M., Matsumoto, S., 2011. Identification of specific sites in the third intracellular loop and carboxyl terminus of the Bombyx mori pheromone biosynthesis activating neuropeptide receptor crucial for ligand-induced internalization. Insect Mol. Biol 20, 801-811.

Iglesias, F., Jacquin-Joly, E., Marco, M., Camps, F., Fabrias, G., 1999. Temporal distribution of PBAN-like immunoreactivity in the hemolymph of Mamestra brassicae females in relation to sex pheromone production and calling behavior. Arch. Insect Biochem. Physiol. 40, 80-87.

Jacquin-Joly, E., Burnet, M., François, M.C., Ammar, D., Meillour, P.N., Descoins, C., 1998. CDNA cloning and sequence determination of the pheromone biosynthesis activating neuropeptide of Mamestra brassicae: a new member of the PBAN family. Insect Biochem. Mol. Biol. 28, 251-258.

Jurenka, R., 2004. Insect pheromone biosynthesis. Top. Curr. Chem. 239, 97-132.

Jurenka, R., 2015. The PRXamide neuropeptide signalling system: conserved in animals. In: Advances in Insect Phsiology, pp. 53-80.

Jurenka, R., Rafaeli, A., 2011. Regulatory role of PBAN in sex pheromone biosynthesis of Heliothine moths. Front. Endocrinol. (Lausanne) 2, 46.

Karlson, P., Butenandt, A., 1959. Pheromones (ectohormones) in insects. Annu. Rev. Entomol. 4, 39-58.

Kawai, T., Katayama, Y., Guo, L., Liu, D., Suzuki, T., Hayakawa, K., Lee, J.M., Nagamine, T., Hull, J.J., Matsumoto, S., Nagasawa, H., Tanokura, M., Nagata, K. 2014. Identification of functionally important residues of the silkmoth pheromone biosynthesis-activating neuropeptide receptor, an insect ortholog of the vertebrate neuromedin U receptor. J. Biol. Chem. 289, 19150-19163.

Kim, Y.-J., Nachman, R.J., Aimanova, K., Gill, S., Adams, M.E., 2008. The pheromone biosynthesis activating neuropeptide (PBAN) receptor of Heliothis virescens: identification, functional expression, and structure-activity relationships of ligand analogs. Peptides 29, 268-275.

Köblös, G., Dankó, T., Sipos, K., Geiger, , Szlanka, T., Fodor, J., Fónagy, A., 2015. The regulation of $\Delta 11$-desaturase gene expression in the pheromone gland of Mamestra brassicae (Lepidoptera; Noctuidae) during pheromonogenesis. Gen. Comp. 221, 217-227.

Krogh, A., Larsson, B., von Heijne, G., Sonnhammer, E.L., 2001. Predicting transmembrane protein topology with a hidden Markov model: application to complete genomes. J. Mol. Biol. 305, 567-580.

Kuniyoshi, H., Kitamura, A., Nagasawa, H., Chuman, T., Shimazaki, K., Anto, T. Suzuki, A., 1991. Structure-activity relationship of pheromone biosynthesis activating neuropeptide (PBAN) from the silkmoth, Bombyx mori. In: Shimonishi, Y. (Ed.), Peptide Chemistry. Protein Research Foundation, Osaka, pp. 251-254.

Larionov, A., Krause, A., Miller, W., 2005. A standard curve based method for relative real time PCR data processing. BMC Bioinf. 6, 62-77.

Le, S.Q., Gascuel, O., 2008. An improved general amino acid replacement matrix. Mol. Biol. Evol. 25, 1307-1320.

Lee, J.M., Hull, J.J., Kawai, T., Goto, C., Kurihara, M., Tanokura, M., Nagata, K., Nagasawa, H., Matsumoto, S., 2012. Re-evaluation of the PBAN receptor molecule: characterization of PBANR variants expressed in the pheromone glands of moths. Front. Endocrinol. (Lausanne) 3, 6 .
Ma, P.W.K., Knipple, D.C., Roelofs, W.L., 1994. Structural organization of the Helicoverpa zea gene encoding the precursor protein for pheromone biosynthesis-activating neuropeptide and other neuropeptides. Proc. Natl. Acad. Sci. U.S.A. 91, 6506-6510.

Ma, P.W.K., Roelofs, W.L., Jurenka, R.A., 1996. Characterization of PBAN and PBAN-encoding gene neuropeptides in the central nervous system of the corn earworm moth, Helicoverpa zea. J. Insect Physiol. 42, 257-266.

Ma, P.W.K., Garden, R.W., Niermann, J.T., O'Connor, M., Sweedler, J.V., Roelofs, W.L., 2000. Characterizing the Hez-PBAN gene products in neuronal clusters with immunocytochemistry and MALDI MS. J. Insect Physiol. 46, 221-230.

Marchese, A., Paing, M.M., Temple, B.R., Trejo, J., 2008. G protein-coupled receptor sorting to endosomes and lysosomes. Annu. Rev. Pharmacol. Toxicol. 48, 601-629.

Markovic, D., Challiss, R.A.J., 2009. Alternative splicing of G protein-coupled receptors: physiology and pathophysiology. Cell. Mol. Life Sci. 66, 3337-3352.

Matsumoto, S., Ozawa, R., Uchiumi, K., Kurihara, M., Mitsui, T., 1995. Intracellular signal transduction of PBAN action in the common cutworm, Spodoptera litura: effects of pharmacological agents on sex pheromone production in vitro. Insect Biochem. Mol. Biol. 25, 1055-1059.

Matsumoto, S., Hull, J.J., Ohnishi, A., Moto, K., Fónagy, A., 2007. Molecular mechanisms underlying sex pheromone production in the silkmoth, Bombyx mori: characterization of the molecular components involved in bombykol biosynthesis. $\mathrm{J}$ Insect Physiol. 53, 752-759.

Matsumoto, S., Ohnishi, A., Lee, J.M., Hull, J.J., 2010. Unraveling the pheromone biosynthesis activating neuropeptide (PBAN) signal transduction cascade that regulates sex pheromone production in moths. Vitam. Horm. 83, 425-445.

Minneman, K.P., 2001. Splice variants of G protein-coupled receptors. Mol. Interv. $1,108-116$

Moore, C.A., Milano, S.K., Benovic, J.L., 2007. Regulation of receptor trafficking by GRKs and arrestins. Annu. Rev. Physiol. 69, 451-482.

Nachman, R.J., Aziz, O.B., Davidovitch, M., Zubrzak, P., Isaac, R.E., Strey, A., Reyes-Rangel, G., Juaristi, E., Williams, H.J., Altstein, M., 2009. Biostable $\beta$-amino acid PK/PBAN analogs: agonist and antagonist properties. Peptides 30, 608-615.

Nagai, T., Ibata, K., Park, E.S., Kubota, M., Mikoshiba, K., Miyawaki, A., 2002. A variant of yellow fluorescent protein with fast and efficient maturation for cell-biological applications. Nat. Biotechnol. 20, 87-90.

Nagy, B., 1970. Rearing of the European corn borer (Ostrinia nubilalis Hbn.) on a simplified artificial diet. Acta Phytopathol. Acad. Sci. Hung. 5, 73-79.

Nusawardani, T., Kroemer, J.A., Choi, M.-Y., Jurenka, R.A., 2013. Identification and characterization of the pyrokinin/pheromone biosynthesis activating neuropeptide family of $\mathrm{G}$ protein-coupled receptors from Ostrinia nubilalis. Insect Mol. Biol. 22, 331-340.

Park, Y., Kim, Y.J., Adams, M.E., 2002. Identification of G protein-coupled receptors for Drosophila PRXamide peptides, CCAP, corazonin, and AKH supports a theory of ligand-receptor coevolution. Proc. Natl. Acad. Sci. U.S.A. 99, 11423-11428.

Peeters, M.C., van Westen, G., Li, Q., Ijzerman, A.P., 2011. Importance of the extracellular loops in $\mathrm{G}$ protein-coupled receptors for ligand recognition and receptor activation. Trends Pharmacol. Sci. 32, 35-42.

Percy, J.E., Weatherston, J., 1974. Gland structure and pheromone production in insects, in: Frontiers of Biology, vol. 32, Pheromones. pp. 11-34.

Rafaeli, A., 2002. Neuroendocrine control of pheromone biosynthesis in moths. Int. Rev. Cytol. 213, 49-91.

Rafaeli, A., 2009. Pheromone biosynthesis activating neuropeptide (PBAN): regulatory role and mode of action. Gen. Comp. Endocrinol. 162, 69-78.

Rafaeli, A., 2011. Moth sex-pheromone production: biosynthetic pathways, regulatory physiology, inhibitory processes and disruption. In: Cauterruccio, L. (Ed.), Moths: Types, Ecological Significance and Control. Nova Science Publisher Inc, pp. 1-29.

Rafaeli, A., Soroker, V., 1989. Cyclic AMP mediation of the hormonal stimulation of ${ }^{14} \mathrm{C}$-acetate incorporation by Heliothis arrnigera pheromone glands in vitro. Mol. Cell. Endocrinol. 65, 43-48.

Rafaeli, A., Soroker, V., Kamensky, B., Raina, A.K., 1990. Action of pheromone biosynthesis activating neuropeptide on in vitro pheromone glands of Heliothis armigera females. J. Insect Physiol. 36, 641-646.

Rafaeli, A., Bober, R., Becker, L., Choi, M.Y., Fuerst, E.J., Jurenka, R., 2007. Spatia distribution and differential expression of the PBAN receptor in tissues of adult Helicoverpa spp. (Lepidoptera: Noctuidae). Insect Mol. Biol. 16, 287-293.

Raina, A.K., Kempe, T.G., 1990. A pentapeptide of the C-terminal sequence of PBAN with pheromonotropic activity. Insect Biochem. 20, 849-851.

Raina, A.K., Jaffe, H., Kempe, T.G., Keim, P., Blacher, R.W., Fales, H.M., Riley, C.T., Klun, J.A., Ridgway, R.L., Hayes, D.K., 1989. Identification of a neuropeptide hormone that regulates sex pheromone production in female moths. Science 244, 796-798

Sato, Y., Oguchi, M., Menjo, N., Imai, K., Saito, H., Ikeda, M., Isobe, M., Yamashita, O., 1993. Precursor polyprotein for multiple neuropeptides secreted from the suboesophageal ganglion of the silkworm Bombyx mori: characterization of the cDNA encoding the diapause hormone precursor and identification of additional peptides. Proc. Natl. Acad. Sci. U.S.A. 90, 3251-3255. 
Sato, Y., Ikeda, M., Yamashita, O., 1994. Neurosecretory cells expressing the gene for common precursor for diapause hormone and pheromone biosynthesis-activating neuropeptide in the suboesophageal ganglion of the silkworm, Bombyx mori. Gen. Comp. Endocrinol. 96, 27-36.

Schindelin, J., Arganda-Carreras, I., Frise, E., Kaynig, V., Longair, M., Pietzsch, T., Preibisch, S., Rueden, C., Saalfeld, S., Schmid, B., Tinevez, J.-Y., White, D.J., Hartenstein, V., Eliceiri, K., Tomancak, P., Cardona, A., 2012. Fiji: an open-source platform for biological-image analysis. Nat. Methods 9, 676-682.

Seck, T., Pellegrini, M., Florea, A.M., Grignoux, V., Baron, R., Mierke, D.F., Horne, W.C., 2005. The delta e13 isoform of the calcitonin receptor forms a six-transmembrane domain receptor with dominant-negative effects on receptor surface expression and signaling. Mol. Endocrinol. 19, 2132-2144.

Shalev, A.H., Altstein, M., 2015. Pheromonotropic and melanotropic PK/PBAN receptors: differential ligand-receptor interactions. Peptides 63, 81-89.

Smith, J.S., Rajagopal, S., 2016. The $\beta$-Arrestins: multifunctional regulators of G protein-coupled receptors. J. Biol. Chem. 291, 8969-8977.

Tamura, K., Stecher, G., Peterson, D., Filipski, A., Kumar, S., 2013. MEGA6: molecular evolutionary genetics analysis version 6.0. Mol. Biol. Evol. 30, 2725-2729.

Thompson, J.D., Gibson, T.J., Plewniak, F., Jeanmougin, F., Higgins, D.G., 1997. The CLUSTAL_X windows interface: flexible strategies for multiple sequence alignment aided by quality analysis tools. Nucleic Acids Res. 25, 4876-4882.

Tillman, J.A., Seybold, S.J., Jurenka, R.A., Blomquist, G.J., 1999. Insect pheromones - an overview of biosynthesis and endocrine regulation. Insect Biochem. Mol. Biol. 29, 481-514.
Watanabe, K., Hull, J.J., Niimi, T., Imai, K., Matsumoto, S., Yaginuma, T., Kataoka, H., 2007. FXPRL-amide peptides induce ecdysteroidogenesis through a G-protein coupled receptor expressed in the prothoracic gland of Bombyx mori. Mol. Cell. Endocrinol. 273, 51-58.

Wurch, T., Lestienne, F., Pauwels, P., 1998. A modified overlap extension PCR method to create chimeric genes in the absence of restriction enzymes. Biotechnol. Tech. 12, 653-657.

Yang, J., Huang, H., Yang, H., He, X., Jiang, X., Shi, Y., Alatangaole, D., Shi, L., Zhou, N., 2013. Specific activation of the G protein-coupled receptor BNGR-A21 by the neuropeptide corazonin from the silkworm, Bombyx mori, dually couples to the Gq and Gs signaling cascades. J. Biol. Chem. 288, 11662-11675.

Yang, J., Shen, Z., Jiang, X., Yang, H., Huang, H., Jin, L., Chen, Y., Shi, L., Zhou, N., 2016. Agonist-activated Bombyx corazonin receptor is internalized via an arrestin-dependent and clathrin-independent pathway. Biochemistry 55, 3874-3887.

Zheng, L., Lytle, C., Njauw, C.N., Altstein, M., Martins-Green, M., 2007. Cloning and characterization of the pheromone biosynthesis activating neuropeptide receptor gene in Spodoptera littoralis larvae. Gene 393, 20-30.

Zmijewski, M.A., Slominski, A.T., 2009. CRF1 receptor splicing in epidermal keratinocytes: potential biological role and environmental regulations. J. Cell. Physiol. 218, 593-602. 